\title{
Scenario evaluation for the management of household solid waste in small Brazilian municipalities
}

\author{
Rafael Mattos Deus ${ }^{1} \cdot$ Rosane Aparecida Gomes Battistelle $^{1}$. \\ Gustavo Henrique Ribeiro Silva ${ }^{2}$
}

Received: 26 February 2016/ Accepted: 26 April 2016/Published online: 19 May 2016

(C) Springer-Verlag Berlin Heidelberg 2016

\begin{abstract}
As achieving Brazil's National Policy on Solid Waste-based goals effectively is not simple, there are alternatives such as intermunicipal cooperation by consortium or privatization. Therefore, this study aimed to evaluate the Greenhouse Gas emissions and energy use of six scenarios in two landfills contexts (private and consortium) for small municipalities (less than 100,000 inhabitants as per Brazilian standards) located in São Paulo, Brazil. Through the technique of scenario building and method of Waste Reduction Model was possible to obtain the total energy, the amount of carbon dioxide equivalent $\left(\mathrm{CO}_{2} \mathrm{E}\right)$ and carbon equivalent $(\mathrm{CE})$ emissions. The best scenario integrates composting and recycling, reducing $72 \%$ for $\mathrm{CO}_{2} \mathrm{E}$ and $\mathrm{CE}$ emissions, and saving about $410 \%$ in energy. The landfill consortium will only take advantage, if the location is the most ideal as far as possible. Small municipalities that do not dispose their waste in landfills compatible with regulatory standards may seek for intermunicipal cooperation and adopt integrated waste-management programmes to reduce their environmental impacts.
\end{abstract}

Rafael Mattos Deus

rafaelmdeus@gmail.com

1 Department of Production Engineering, Faculty of Engineering of Bauru, São Paulo State University - FEB/ UNESP, Av. Eng. Luiz Edmundo Carrijo Coube, 14-01, Bauru, SP CEP 17033-360, Brazil

2 Department of Civil and Environmental Engineering, Faculty of Engineering of Bauru, São Paulo State University - FEB/ UNESP, Av. Eng. Luiz Edmundo Carrijo Coube, 14-01, Bauru, SP CEP 17033-360, Brazil
Keywords Household solid waste - Integrated waste management $\cdot$ Recycling $\cdot$ Composting $\cdot$ Small municipalities

\section{Introduction and background}

The municipal infrastructure includes water supply, solid waste management, drainage systems, sewer services, power generation facilities, roads, mass transportation, power generation, telecommunications, public lighting, security, post services, sidewalks, public greenery, etc. The provision of infrastructure is essential and involves several functions such as planning, finance, construction, ownership, operation and maintenance (Alm 2015).

As for the solid waste system, it is a problem accompanying completely human and urban development, which recently experienced its compositional changes due to the increase in the industrial production of products like plastic. It can also be noted that only from the decade of 1970s, waste began to have a major environmental significance because it was covered in large global meetings focused on the environment (Worrell and Vesilind 2011). Therefore, different from the past when there was no proper disposal for waste, today in the cities, the waste are collected and disposed of to specific places that are environmentally protected, such as sanitary or bioreactor landfills (Sethi et al. 2013). Or it is processed for reuse, although there are many municipalities in Brazil which have irregular allocation of the waste disposal on the open dumps (Ministério do Meio Ambiente 2012), which means the waste have been disposed of in places without leachate treatment, protection by a geomembrane at the bottom and treatment of gases (Guerrero et al. 2013). 
It is not just enough to stimulate environmental awareness in people, but the system must also have an efficient and effective municipal infrastructure; the efficient infrastructure means the right use of the budget for the collection, transportation and right disposal of solid waste, and the effective infrastructure means that the services have been done to the entire population and all its surroundings (Koushki et al. 2004).

Regarding the composition of municipal solid waste in Brazil (Fig. 1), similar to other countries-whether developed or not, the largest share (51.4\%) of them is composed of organic waste, with the materials that can be recycled coming next $(31.9 \%)$ which are composed of glass, plastics, paper, steel and aluminium (Massukado et al. 2013).

Although composting is environmentally an appropriate type of treatment for organic waste, the application of this treatment technology is very much limited in Brazil, because of constraints such as the low separation rate of organic materials, difficulty of process maintenance and operation, difficult market penetration (Secretaria do Meio Ambiente 2014a) and lack of investment and appropriate technology for collection (Massukado et al. 2013). In 2008, only $3.8 \%$ of the Brazilian municipalities had composting plants, whereas in the state of São Paulo, only $2.8 \%$ of the municipalities were having such units (Instituto de Pesquisa Econômica Aplicada 2012).

Regarding recycling, it can be stated that it has a great potential for reducing emissions of greenhouse gases, lower energy consumption and even lower water consumption due to the substitution of virgin raw materials, as highlighted by Menikpura et al. (2013), Zaman (2014), Mahmoudkhani et al. (2014), and Fujii et al. (2014). The

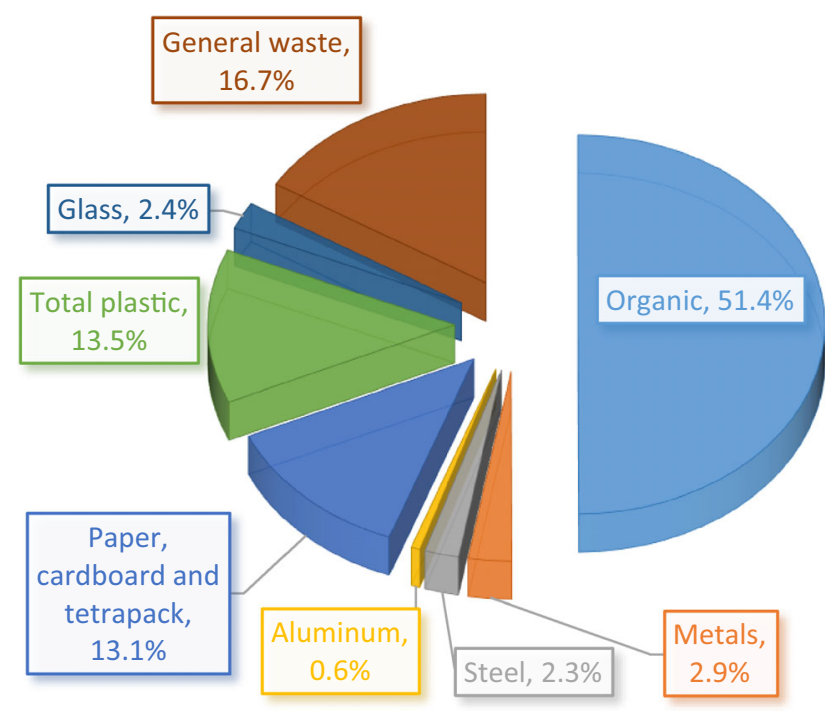

Fig. 1 Physical composition of municipal solid waste in Brazil. Source: Massukado et al. (2013) amounts of municipal solid waste (MSW) in Brazil available for sorting units for recycling were $1.5 \%$ in 2000 and $1.4 \%$ in 2008 , while at the same time, the number of municipalities using this system has risen from 4.5 to $11.6 \%$ (Massukado et al. 2013).

Another important factor in the Brazilian context is although there is an increase in the environmentally appropriate method adopted for the final disposal, which means the disposal of waste in sanitary landfills (disposal of waste in place with soil sealing, lack of collectors, gas drainage system, rainwater and leachate waters systems, and then covered with soil) complying with operational standards, there are still many municipalities that dispose of waste on open dumps (disposal of waste on the soil without any technical safeguards or controls) and controlled landfills (disposal where the care is taken for only recovering the waste mixed with soil) (Ministério do Meio Ambiente 2012), for which guidelines have not been effectively and clearly explained by the National Policy on Solid Waste in Brazil-NPSW (Brasil 2010). The municipalities most affected by inappropriate disposal are the small ones (Table 1). To change this scenario, the current solid waste policy in Brazil stimulates municipalities to adopt consortium management, i.e. an intermunicipal cooperation, which can enable the implementation of joint activities, pressure coordination and capacity of planning vision and intervention (Matos and Dias 2011).

Through the consortium, it is possible to perform the environmentally appropriate destination and treatment of solid waste, eradicate open dumps and controlled landfill, encourage recycling cooperatives and involve environmental education to improve the selective collection (Matos and Dias 2011).

\section{Solid waste and climate change}

The National Policy on Solid Waste in Brazil (NPSW), which was decreed in 2010, explores several terms such as final environmentally appropriate destination and integrated management, and also exposits 11 principles and 15 key objectives. Then the NPSW discusses the instruments used to achieve the goals, and one of those instruments is intermunicipal cooperation, encouraging the adoption of consortia or other forms of cooperation among federal entities (Brasil 2010), in order to increase the exploitation scales and reduction of the costs involved (de Jabbour et al. 2014).

According to NPSW, the municipalities must create an integrated solid waste-management plan, including targeting of the reduction, reuse, selective collection, and recycling; reducing the amount of waste sent for final disposal; taking preventive and corrective actions, among others. 
Table 1 Numbers of waste destination units in 2000 and 2008 considering only the open dumps, controlled landfills, and sanitary landfills. Source: Adapted from Ministério do Meio Ambiente (2012)

\begin{tabular}{|c|c|c|c|c|c|c|}
\hline \multirow{3}{*}{$\begin{array}{l}\text { Destination } \\
\text { Year } \\
\text { Municipality size }\end{array}$} & \multicolumn{2}{|c|}{ Open dumps } & \multicolumn{2}{|c|}{ Controlled landfill } & \multicolumn{2}{|c|}{ Sanitary landfill } \\
\hline & 2000 & 2008 & 2000 & 2008 & 2000 & 2008 \\
\hline & \multicolumn{6}{|c|}{ Quantity of destination units } \\
\hline Small municipalities & 4507 & 2863 & 1096 & 1226 & 773 & 1483 \\
\hline Medium-sized municipalities & 133 & 42 & 130 & 78 & 125 & 207 \\
\hline Large municipalities & 2 & 1 & 5 & 6 & 33 & 33 \\
\hline Total in Brazil & 4642 & 2906 & 1231 & 1310 & 931 & 1723 \\
\hline
\end{tabular}

Good practices recommended by NPSW include the following: increasing coverage of selective waste collection and reverse logistics; decontamination of contaminated areas; extinction of open dumps and rejection of disposal in sanitary landfills, after exhausting all forms of treatment; integration management covering reuse, recycling, composting, recovering, and energy reutilization; introduction of service charges; private and non-governmental organizations' partnerships; economic incentives, among others (Brasil 2010).

The Art. 45 emphasizes the importance of public consortia for NPSW because it allows for the management and administrative decentralization, and affords priority in obtaining the incentives established by the Federal Government. After some consideration, the NPSW ends with the stipulation of some deadlines, as the final disposal in an environmentally appropriate way. This is a great challenge, especially for small municipalities, which have limitations in both financial and human resources, and thus have lower intellectual capacity to develop effective projects and apply them, compared to medium or large municipalities.

The NPSW complements the National Policy on Climate Change (NPCC) of Brazil; it is first clear that the planet is undergoing changes in its various atmospheric compositions, lands, biomes, among others. Most of these changes are anthropogenic, which are inevitable changes in all spheres of society, beyond the formulation of specific government policies aimed at sustainability, thus changing the current way (IPCC 2014a, b, c).

These climate changes have affected natural ecosystems, biodiversity, agriculture, water resources, etc. The distribution pattern of biomes in South America, as well as their rainfall rates, may be more affected by climate changes in addition to the changes in land use (Nobre et al. 2007).

Therefore, climate change, as an environmental sustainability motivator of the treatment of waste (Zaman 2013), has stimulated the formulation of policies. In Brazil, the NPCC was instituted in 2009., per Law No. 12,187. It formalizes the voluntary commitment of Brazil to the United Nation Framework Convention on Climate Change to reduce the Greenhouse Gas Emissions to range between 36.1 and $38.9 \%$ of projected emissions by 2020 (Brasil 2009).

Regarding NPCC, the National Plan on Climate Change, with the aims of reducing pressure on natural resources and the promotion of energy conservation, outlines a target of increasing the recycling of solid waste to $20 \%$ by the year 2015 (Brasil 2008).

\section{Decision support}

There are two categories for the decision-making process as the most effective forms of management: (1) Engineering Systems, including, for example, economic optimization and cost-benefit analyses, and (2) Evaluation System, including, for example, the lifecycle assessment (LCA). One difference between the two categories lies in the kind of decision tools that are designed to inform. The first one focuses on the support system design, while the second one examines how a system is executed (Chang et al. 2011).

One of the available various techniques and tools that analyse solid waste-management systems (Pires et al. 2011) is the construction of scenarios, which deals with complex and dynamic systems and is a part of the planning process to provide viable guidelines for decision making. The technique of scenarios, such as a prospective study, aims to describe alternative futures in order to provide support in the decision making and choosing the best alternative. Thus, this technique is the description of a possible or a desirable future and the entire process or path that connects with the initial situation (Buarque 2003). Therefore, scenarios can contribute to real options on three main levels: (1) assisting in the identification of future options; (2) helping in the timely decision for the implementation of options; (3) providing important information with respect to the evaluation process of real options (Cornelius et al. 2005). 
The use of scenarios is embracing and applicable to various areas and objectives (Bradfield et al. 2005). Therefore, the objective of this research is to create alternative scenarios of solid waste management for small municipalities, propose and analyse the most appropriate setting for the final disposal of solid waste in private and public by consortium.

\section{Materials and methods}

This is a quantitative research involving secondary data under simulations, a method widely used to analyse complex systems, imitating the real system operations (Lindgren and Bandhold 2003).

This study focuses on nine small municipalities (less than 100,000 inhabitants) of São Paulo state, Brazil (Table 2). These municipalities have not received the certification in the "Município VerdeAzul 2014" programme, because of having low grades ( 80 points is the minimum required for certification). This programme stimulates and empowers municipalities in the implementation and development of a strategic environmental agenda, within 10 policies, and one of them is solid waste (Secretaria do Meio Ambiente 2014b). Moreover, none of them has recycling and/or composting programmes, and four of them have programme for final disposal on irregular landfills.

The scenarios chosen for this research involve the projection of the status of solid waste management for the future 15 years. They are for private implemented landfill and supposed consortium, as follows:

- 1 regional landfill

- 1 regional landfill less $10 \%$ of total waste generation

- 1 regional landfill plus $10 \%$ of the total waste generation

- 1 regional landfill with recycling of $20 \%$ of the total

- 1 regional landfill with composting of $20 \%$ of the total
- 1 regional landfill with recycling of $20 \%$ and composting of $20 \%$ of the total.

This study established a target of $20 \%$ over the total of 15 years, starting at $5 \%$ and finishing with $35 \%$, with an annual goal of $2 \%$ increment. This goal was set due to the low current capacity of Brazilian municipalities on composting and recycling management (just $5.44 \%$ of all), and this goal was taken as the basis for the National Plan Climate Change that is $20 \%$ for 2015 (Brasil 2008).

This study did not include the energy recovery in landfills, even if it is environmentally important, because there must be technical and environmental feasibility (Brasil 2010), besides being recommended financially and economically to populations over 200,000 habitats, and for population less than this figure, changes in public policy are necessary (Barros et al. 2014). Therefore, it would be impracticable for the region of the municipalities considered under this study (total of 151,310 inhabitants). This study also did not simulate the implementation of incineration, even if it is scored as a great alternative especially when there is energy recovery (Tan et al. 2014), but it is not recommended for developing countries or non-OECD (Aprilia et al. 2012).

Based on the more complex indicators classified by Greene and Tonjes (2014), there are several models in the literature that determine the best emission-reduction options for greenhouse gas (GHG) emissions and energy use. For this study, we used the Waste Reduction Model (WARM), created by the US Environmental Protection Agency, which has been widely used in various contexts and academic papers (Morrissey and Browne 2004; Vergara et al. 2011; Barros et al. 2013; Greene and Tonjes 2014; Mahmoudkhani et al. 2014; Lai et al. 2014).

The outputs are Energy Use in GJ (gigajoule), $\mathrm{CO}_{2} \mathrm{E}$ (carbon dioxide equivalent), and $\mathrm{CE}$ (carbon equivalent) emissions in Gg (gigagram). The data of GHG emissions have been developed according to the Life Cycle Assessment (LCA) using the estimation techniques produced by
Table 2 Municipalities involved in this study and their respective populations and grades of the "Município VerdeAzul 2014" programme Source: IBGE (2010) and Secretaria do Meio Ambiente (2014b)

\begin{tabular}{lrc}
\hline Municipality & Population (2010) & $\begin{array}{l}\text { "Município VerdeAzul 2014" } \\
\text { programme grade }\end{array}$ \\
\hline A & 2493 & 7.56 \\
B & 3696 & 0 \\
C & 10,223 & 31.73 \\
D & 30,091 & 34.66 \\
E & 77,039 & 37.38 \\
F & 6590 & 1.39 \\
G & 11,309 & 1.07 \\
H & 4077 & 9.25 \\
I & 5792 & 13.88
\end{tabular}


Table 3 Gravimetric composition of household solid waste. Source: Integrated Sanitation Plan of municipalities of this study

\begin{tabular}{lc}
\hline Components & Gravimetric composition $(\%)$ \\
\hline Paper/cardboard & 9.60 \\
Long-life carton & 1.00 \\
Rigid plastic & 6.30 \\
Soft plastic & 6.70 \\
PET packaging & 0.60 \\
Ferrous metal & 1.40 \\
Non-ferrous metal & 0.40 \\
Glasses & 1.70 \\
Polystyrene & 0.20 \\
Rags/cloths & 2.20 \\
Rubber & 0.20 \\
Subtotal & 30.30 \\
Organic & 62.90 \\
Wood & 1.20 \\
Ground/stones & 2.10 \\
Batteries & 0.00 \\
Miscellaneous & 2.00 \\
Losses & 1.50 \\
Subtotal & 69.70 \\
Total & 100.00 \\
\hline
\end{tabular}

GHG emission inventories (Environmental Protection Agency 2006).

For projections of scenarios and analyses in the WARM system, we used the gravimetric compositions shown in Table 3 , and indicated by sanitary municipal plans of the municipalities involved.

For composting and recycling plants, both were by consortium and centralizationed at the municipality were chosen. To set the municipality to receive these materials for recycling and composting, and landfill location of the consortium, we used the centre of gravity method (Corrêa and Corrêa 2009). This method tries to find the centre of gravity of the locations by means of $x$ and $y$ coordinates as follows:

$C x=\frac{\sum d i x V i}{\sum V i}$ e $C y=\frac{\sum d i y V i}{\sum V i}$

where $C x=x$ coordinate (horizontal axis) of the centre of gravity; $C y=y$ coordinate (vertical axis) of the centre of gravity; $d i x=\mathrm{x}$ coordinate of the $i$ site diy $=\mathrm{y}$ coordinate of the $i$ site; $V i=$ volume of waste generated $i$ site.

In this case, the selected city was $F$, with an average of $45.9 \mathrm{~km}$. It is noteworthy that the minimization of gas consumption of the vehicles achieved with the decreasing distance is a significant aspect to reduce the potential of environmental impact (dos Santos et al. 2014).
The municipality responsible for the particular landfill is D, which already operates a private intermunicipal landfill with Quality Index Waste Landfill score of 9.4 in 2012 (CETESB 2013).

For the population projection, we used the data from the State System of Data Analysis (SEADE) of the State of São Paulo. The projection of generation of solid waste was extracted from the Basic Sanitation Integrated Municipal Plans of each municipality, as below:

Generation of MSW $=(\text { Population } / 2,990.32)^{1.258}$

From this formula, a production curve adjusted was created by the following factor:

$f a=\frac{P r-P c}{P r}$

where $f a$ is the factor of adjustment (to adjust the points to the resulting curve); $\operatorname{Pr}$ is the production of solid waste in $2010 ; P c$ is the production calculated for the 2010 population.

The projection of municipal solid waste was calculated using the following equation and adjustment factor:

$P p=P c+(P c \cdot f a)$

where $P p$ is the projected production of solid waste; $P c$ is the production calculated; and $f a$ is the factor of adjustment.

\section{Results and discussion}

As shown in Table 4, the baseline scenario of municipalities over the 15 years analysed emits 113.76 $\mathrm{GgCO}_{2} \mathrm{E}, 31.03 \mathrm{GgCE}$ and consume 165.45 GJ. This scenario has better results in all aspects analysed than scenario 1 for the particular landfill, which emits 114.41 $\mathrm{GgCO}_{2} \mathrm{E}, 31.20 \mathrm{GgCE}$ and consume $174.83 \mathrm{GJ}$, and the scenario 1 to the consortium emits $114.12 \mathrm{GgCO}_{2} \mathrm{E}$, $31.12 \mathrm{GgCE}$ and consume 170.71 GJ. However, these differences are not considered as significant when viewed in Figs. 2, 3 and 4, which is possible to check a low difference that involves the change of the landfill site for those municipalities.

The change of the landfill site in scenario 1 compared to the baseline scenario reinforces the importance of transport in the waste-management system. Because transport worldwide is responsible for about $26 \%$ of $\mathrm{CO}_{2}$ global emissions (Chapman 2007), it is a major pollutant system and also an environmental impact generator (dos Santos et al. 2014). It also has a high energy consumption (Larsen et al. 2009), and several LCA studies identify the distance travelled as a fundamental basis for environmental impacts (Yang et al. 2014). 
Table 4 Comparison between the scenarios of all municipalities according to the total waste sent to landfill,

15 years: emission of Greenhouse Gases and Energy use

\begin{tabular}{|c|c|c|c|c|c|c|c|}
\hline & \multirow[t]{2}{*}{ Baseline scenario } & \multicolumn{6}{|c|}{ Scenarios-private landfill } \\
\hline & & 1 & 2 & 3 & 4 & 5 & 6 \\
\hline $\mathrm{CO}_{2} \mathrm{E}(\mathrm{Gg})$ & 113.76 & 114.41 & 102.97 & 125.85 & 59.02 & 86.53 & 31.14 \\
\hline Energy use (GJ) & 165.45 & 174.83 & 157.29 & 192.19 & -704.03 & 186.23 & -676.73 \\
\hline \multirow[t]{3}{*}{$\mathrm{CE}(\mathrm{Gg})$} & 31.03 & 31.20 & 28.08 & 34.32 & 16.10 & 23.60 & 8.49 \\
\hline & Baseline scenario & \multicolumn{6}{|c|}{ Scenarios-consortium } \\
\hline & & 1 & 2 & 3 & 4 & 5 & 6 \\
\hline $\mathrm{CO}_{2} \mathrm{E}(\mathrm{Gg})$ & 113.76 & 114.12 & 102.71 & 125.55 & 58.76 & 86.29 & 30.93 \\
\hline Energy use (GJ) & 165.45 & 170.71 & 153.64 & 187.94 & -691.96 & 183.80 & -679.81 \\
\hline $\mathrm{CE}(\mathrm{Gg})$ & 31.03 & 31.12 & 28.01 & 34.24 & 16.03 & 23.53 & 8.43 \\
\hline
\end{tabular}

Total of CO2E (Gg)

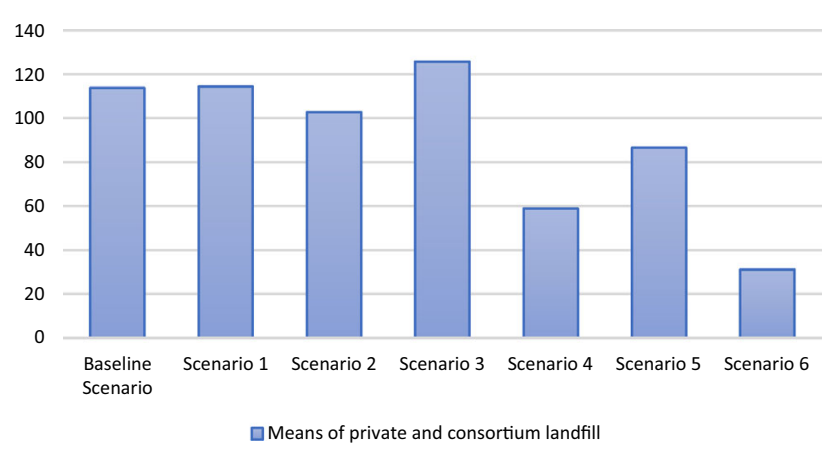

Fig. 2 Comparison of means of carbon dioxide equivalent (gigagram) emission between scenarios

Total of Energy (GJ)

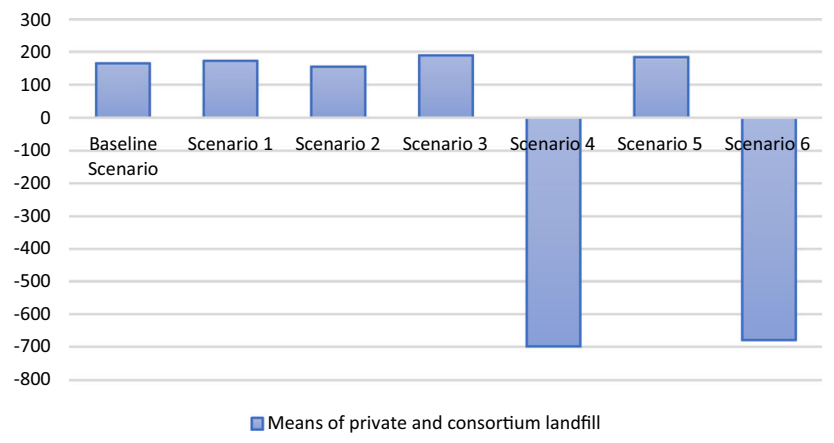

Fig. 3 Comparison of the means of total energy (gigajoule) between scenarios

In scenario 2 (Table 4), which is implemented to achieve a goal of $10 \%$ reduction of waste at source, there is an incensement compared to the baseline scenario and scenario 1 (Figs. 2, 3, 4). In scenario 2, the particular landfill emits $102.97 \mathrm{GgCO}_{2} \mathrm{E}, 28.08 \mathrm{GgCE}$ and consumes 157.29 GJ, which represents a reduction compared to the baseline scenarios of, respectively, 9.49, 9.48 and $4.93 \%$.

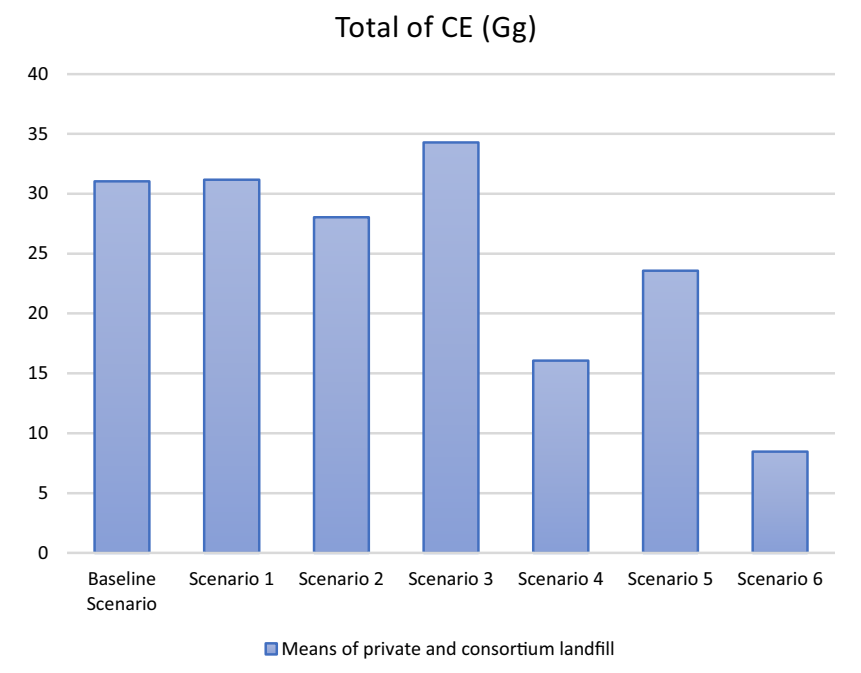

Fig. 4 Comparison of means of carbon equivalent (gigagram) emission between scenarios

The consortium emits $102.71 \mathrm{GgCO}_{2} \mathrm{E}, 28.01 \mathrm{GgCE}$ and consumes $153.64 \mathrm{GJ}$, which represents a reduction from the baseline scenarios, respectively, of 9.71, 9.72 and $7.14 \%$.

This reduction confirmed for scenario 2 is caused mainly by the reduction in the waste generation, and not by the changes in the final disposal site, which in the case for most municipalities is located at a greater distance. Recalling that some municipalities have irregular landfills, the reduction of total energy (Fig. 3) is therefore less pronounced, probably due to the lower energy consumption of transport (Larsen et al. 2009). Note also that for consortium, the reduction is $2.21 \%$ higher than that of a particular landfill, because the method for selecting the consortium landfill site takes into account the distance and the amount of waste, which would be the ideal distance from the landfill for intermunicipal cooperation.

An important aspect of scenario 2 is the first principle of the 3Rs (reduce, reuse and recycle), and as Gentil et al. 
(2011) show, it is important to consider the waste prevention input within the system, because this factor has a positive effect on various categories of impact, such as the reduction of up to $12 \%$ of the global warming potential. An example of the application of the reduction principle is the city of $\mathrm{Cebu}$ in Philippines, which achieved a reduction rate of $30 \%$ of municipal solid waste in 3 years, due to a high degree of political commitment, planning and strategic development, involving partnerships of stakeholders (Premakumara et al. 2014).

In contrast to scenario 2, the scenario 3 (Table 4) simulates the growth of $10 \%$ of the waste over time more than the current trend, due, for example, to changes in consumption patterns, resulting in positive correlation with the increase of cities GDP (Adhikari et al. 2006). As expected, the third scenario has the worst score of all the scenarios (Figs. 2, 3, 4).

For the particular landfill, scenario 3 emits 125.85 $\mathrm{GgCO}_{2} \mathrm{E}, 34.32 \mathrm{GgCE}$ and consumes $192.19 \mathrm{GJ}$, which represents an increase over the baseline scenarios, respectively, of $10.63,10.63$ and $16.16 \%$. The consortium scenario emits $125.55 \mathrm{GgCO}_{2} \mathrm{E}, 34.24 \mathrm{GgCE}$ and consumes 187.94 GJ, which represents an increase over the baseline scenarios, respectively, of $10.36,10.36$ and $13.59 \%$. Again, we observe the difference, especially in energy consumption $(2.57 \%)$, when comparing simulations between final destination locations.

Similar to scenario 3 of this study, de Melo et al. (2009) observed that the scenario achieving the highest financial cost and methane production, among those of their studies, was the scenario with an increase of $5 \%$ in total waste generation, showing the impact of increased waste generation. Note that if the world's population does not have the necessary socio-economic development and is without increased environmental awareness, the growth trend of waste generation will continue (Hoornweg et al. 2013).

Scenario 4, in which there is $20 \%$ total recycling of recyclable waste, has featured in all aspects analysed (Table 4), mainly in energy consumption (Fig. 3). Consistent with other authors, recycling has great potential to reduce emissions of greenhouse gases, energy consumption and even water consumption due to the substitution of virgin raw materials (Menikpura et al. 2013).

Therefore, in a particular landfill, scenario 4 emits 59.02 $\mathrm{GgCO}_{2} \mathrm{E}, 16.10 \mathrm{GgCE}$ and consumes an energy of 704.03 $\mathrm{GJ}$, which is a huge reduction from the baseline scenarios, respectively, of $48.12,48.12$ and $425.52 \%$. The consortium emits $58.76 \mathrm{GgCO}_{2} \mathrm{E}, 16.03 \mathrm{GgCE}$, and consumes an energy of $691.96 \mathrm{GJ}$, which represents a reduction from the baseline scenarios, respectively, of 48.35, 48.35 and $418.22 \%$. Note the significant differences in all the aspects analysed, especially in energy consumption, which is the best result compared to all other scenarios (Fig. 3). When comparing the simulations between the final destinations' locations, the difference is $7.3 \%$ compared to the baseline scenario for the total energy.

Scenario 5 (Table 4) involves $20 \%$ of composting of organic materials; this particular landfill scenario emits 86.53 $\mathrm{GgCO}_{2} \mathrm{E}$ and $23.60 \mathrm{GgCE}$, which represents a reduction from baseline scenario of $23.94 \%$ for both. The energy consumption is $186.23 \mathrm{GJ}$, representing an increase compared to the baseline scenario of $12.56 \%$. The consortium scenario emits $86.29 \mathrm{GgCO}_{2} \mathrm{E}$ and $23.53 \mathrm{GgCE}$, which represents a reduction compared to the baseline scenario of $24.15 \%$ for both. The energy consumption is $183.80 \mathrm{GJ}$, representing an increase compared to the baseline scenario of $11.09 \%$. Comparing the differences between the locations of the landfill, the differences are small: $0.21 \%$ for $\mathrm{CO} 2 \mathrm{e}$ and $\mathrm{CE}$, and $1.47 \%$ for energy use.

The biggest advantage of scenario 5 is the lowest $\mathrm{CO}_{2} \mathrm{E}$ and CE emissions (Figs. 2, 4) compared to baseline scenarios and 1-3 scenarios. Lou and Nair (2009) state that the anaerobic decomposition that occurs commonly in landfills producing $\mathrm{CH}_{4}$ has a global warming potential 25 times greater than $\mathrm{CO}_{2}$. Taheri et al. (2014) used the Rapid Impact Assessment Matrix and recommended composting together with the landfill. However, the LCA of Abduli et al. (2011) for Tehran shows that the combined landfill and composting scenario has an environmental impact than does the landfill scenario only. These authors conclude that the landfill scenario is the most viable option in the environmental and economic aspects of the city under study.

The disadvantage of scenario 5 is the increase in energy consumption (Fig. 3), which is just more than that of scenario 3 , of $3.6 \%$ compared to the baseline scenario, when the setting is private and $2.5 \%$ with the consortium. This is due to the fact that the production of compounds, especially of higher quality, requires more energy (Lou and Nair 2009).

Aye and Widjaya (2006) compared scenarios for various treatments, such as centralized composting, landfill with electricity production, biogas electricity generation and landfill versus baseline scenario. Those authors concluded that centralized composting has the highest potential for success in the treatment of waste from traditional markets, which are the second largest generators of waste after the municipal solid waste in Indonesia. Composting has the best cost-benefit ratio, in addition to moderate environmental impacts.

Scenario 6 (Table 4), in which there is total recycling of $20 \%$ of recyclable waste and composting of $20 \%$ of organic compounds, has featured in all aspects analysed, especially in lower emissions of $\mathrm{CO}_{2} \mathrm{E}$ and $\mathrm{CE}$ (Figs. 2, 4), because there is a great potential of recycling to reduce emissions of greenhouse gases, energy consumption and 
even water consumption due to the substitution of virgin raw materials (Menikpura et al. 2013). Moreover, the lower GHG emission occurs due to the integration of composting and recycling system similar to study of Mahmoudkhani et al. (2014), so the composting and recycling together has great potential of $\mathrm{GHG}$ emission reduction and energy consumption.

Thus, a particular landfill, in scenario 6, emits 31.14 $\mathrm{GgCO}_{2} \mathrm{E}, 8.49 \mathrm{GgCE}$ and consumes an energy of 676.73 GJ, which is a huge reduction from the baseline scenario, respectively, 72.62, 72.62 and $409.02 \%$. The consortium emits $30.93 \mathrm{GgCO}_{2} \mathrm{E}, 8.43 \mathrm{GgCE}$ and consumes an energy of $679.81 \mathrm{GJ}$, which represents a reduction from the baseline, respectively, $72.82,72.82$, and $410.88 \%$.

Scenario 6 has the lowest emission values of $\mathrm{CO}_{2} \mathrm{E}$ and $\mathrm{CE}$ and the second best result for the energy consumption, because with the integration of recycling and composting, GHG emissions greatly decrease compared to the baseline scenario. The total energy consumption also decreases (Fig. 3), and is negative, but slightly less than scenario 4, by about $16.5 \%$ for the particular landfill and $7.34 \%$ for the consortium. This difference is due to lower energy use in composting.

Therefore, the improved scenario, from the analysis of the data of tables and graphics, is the one due to the scenario 6. For $\mathrm{CO}_{2} \mathrm{E}$ and $\mathrm{CE}$ emissions, this scenario for particular landfill has an advantage of $24.5 \%$, for both GHG emissions compared to scenario 4 and $24.47 \%$ for consortium. However, scenario 4 has an advantage over the scenario 6 with a decreased energy consumptions of $16.5 \%$ in particular landfill and $7.34 \%$ in the consortium.

In scenario 6 , the differences between the particular landfill and the consortium are small. The consortium has the advantage of $0.2 \%$ of $\mathrm{CO}_{2} \mathrm{E}$ and $\mathrm{CE}$ emissions, compared to the baseline scenario, and $1.86 \%$ for the energy consumption.

The excellent results of scenario 6 confirm the importance of integrated management as highlighted by Antonopoulos et al. (2013), Menikpura et al. (2013), Song et al. (2013) and Herva et al. (2014), which involves various techniques, technologies, strategies and programmes to achieve certain goals (Tchobanoglous and Kreith 2002).

Note that composting as a technology for the integrated management is projected as the Strength, because it employs a biological process with the possibility of getting rich nutrients in organic fertilizers, while its weakness is that only biodegradable waste can be used in addition to the difficulty to control emissions. This technique has the Opportunity to recover materials and turn them into fertilizer and the possibility of generating biogas. The biggest Threats of this process are the contamination of air, soil and water due to inadequate management (Zaman 2013).
The Strength of landfill lies in the utilization of the natural decomposition process with a large volume and in a controlled environment. However, the Weakness is the need for large areas for a long time, besides the difficulty in controlling emission and the prohibitive cost. The Opportunity is the possibility to reuse biogas and the use of landfills subsequently closed. Its greatest Threat is the potential for environmental contamination of air, water and soil due to inadequate management (Zaman 2013).

\section{Final considerations}

Small municipalities that do not have landfills compatible with regulatory standards need to change this panorama seeking intermunicipal cooperation with the creation of public consortia or the privatization of the final disposal system of waste in a particular landfill.

The increased waste due to GDP growth and economic development without an integrated management increases the environmental impacts related to greenhouse gas emissions $\left(\mathrm{CO}_{2}\right.$ and $\mathrm{C}$ equivalents) and energy consumption. In this study, the growth of $10 \%$ of the waste generation over time represents increases of 10.5, 10.5 and $14.9 \%$ in $\mathrm{CO}_{2} \mathrm{E}, \mathrm{CE}$ emissions and energy use, respectively.

If a municipal programme, through a reduction in the generation of waste, can contribute to the environmental aspects of municipal solid waste management, which is about $10 \%$, it can contribute to a reduction of 9.6, 9.6, and $6.0 \%$ for $\mathrm{CO}_{2} \mathrm{E}, \mathrm{CE}$ emissions, and energy use, respectively.

The best scenario, regardless of whether it is through a consortium or private, is the one that integrates techniques, technologies, strategies and programmes to achieve maximum efficiency with the lowest energy consumption and lower GHG emissions. In our studies, recycling and composting (for $20 \%$ of total years) contribute toward a huge reduction of $72.7 \% \mathrm{CO}_{2} \mathrm{E}$ and $410,0 \%$ of $\mathrm{CE}$ emissions and avoid high energy consumption, respectively, causing a difference of $\%$ in energy use; this is because recycling reinstates raw materials back into the life cycle and avoids new material extractions that consume higher energy.

The results showed a few differences between the consortium and private landfills; thus, the landfill consortium will only take advantage of the particular landfill, if the location is the most ideally possible like the equilibrium point, because the distance travelled by transport is an important point of environmental impact. This means for low environmental impacts, the small municipalities must perform the following: (1) suit the current status of irregular disposal; (2) utilize integrated management with 
alternatives that avoid landfill disposal; (3) accomplish intermunicipal cooperation (with public or private partnership), as recommended by the NPSW.

Future studies may incorporate economic aspects, such as costs and revenue calculations, to allow for better analysis of the results, in addition to the analysis of potential energy and GHG emissions. These three assessments provide valuable information for policy-making in municipal solid waste-management practices in order to be more efficient and effective in achieving the low cost, energy benefits and environmental protection (Tan et al. 2014). Besides the above aspects, social aspects that would also give strength to the study can be integrated in the analysis (Aprilia and Tezuka 2013).

\section{References}

Abduli MA, Naghib A, Yonesi M, Akbari A (2011) Life cycle assessment (LCA) of solid waste management strategies in Tehran: landfill and composting plus landfill. Environ Monit Assess 178:487-498. doi:10.1007/s10661-010-1707-x

Adhikari BK, Barrington S, Martinez J (2006) Predicted growth of world urban food waste and methane production. Waste Manag Res 24:421-433. doi:10.1177/0734242X06067767

Alm J (2015) Financing urban infrastructure: knowns, unknowns, and a way forward. J Econ Surv 29:230-262. doi:10.1111/joes.12045

Antonopoulos I-S, Karagiannidis A, Tsatsarelis T, Perkoulidis G (2013) Applying waste management scenarios in the Peloponnese Region in Greece: a critical analysis in the frame of life cycle assessment. Environ Sci Pollut Res Int 20:2499-2511. doi:10.1007/s11356-012-1139-y

Aprilia A, Tezuka T (2013) GHG emissions estimation from household solid waste management in Jakarta, Indonesia. J Energy Power Eng 7:661-668

Aprilia A, Tezuka T, Spaargaren G (2012) Household solid waste management in Jakarta, Indonesia: a socio-economic evaluation. In: Marmolejo Rebellon LF (eds) Waste management—an integrated vision. InTech. Available from http://www.intechopen.com/books/ waste-management-an-integrated-vision/household-solid-wasteman agement-in-jakarta-indonesia-a-socio-economic-evaluation

Aye L, Widjaya ER (2006) Environmental and economic analyses of waste disposal options for traditional markets in Indonesia. Waste Manag 26:1180-1191. doi:10.1016/j.wasman.2005.09. 010

Barros RM, Filho GLT, Moura JS et al (2013) Design and implementation study of a permanent selective collection program (PSCP) on a University campus in Brazil. Resour Conserv Recycl 80:97-106. doi:10.1016/j.resconrec.2013.09.005

Barros RM, Tiago Filho GL, Silva TR (2014) The electric energy potential of landfill biogas in Brazil. Energy Policy 65:150-164. doi:10.1016/j.enpol.2013.10.028

Bradfield R, Wright G, Burt G et al (2005) The origins and evolution of scenario techniques in long range business planning. Futures 37:795-812. doi:10.1016/j.futures.2005.01.003

Brasil (2008) Plano Nacional sobre Mudança do Clima: PNMC Brasil. Comitê Interministerial sobre Mudança do Clima, Brasília

Brasil (2009) Lei $\mathrm{n}^{\circ}$ 12.187, de 29 de dezembro de 2009: Institui a Política Nacional sobre Mudança do Clima - PNMC e dá outras providências, Brasil
Brasil (2010) Lei $\mathrm{n}^{\mathrm{O}}$ 12.305, de 02 de agosto de 2010: Institui a Política Nacional de Resíduos Sólidos; altera a Lei no 9.605, de 12 de fevereiro de 1998; e dá outras providências. Brasília, Brasil

Buarque SC (2003) Metodologia e técnicas de construção de cenários. IPEA, Brasília

CETESB (2013) Inventário estadual de resíduos sólidos domiciliares 2012. CETESB, São Paulo

Chang N-B, Pires A, Martinho G (2011) Empowering systems analysis for solid waste management: challenges, trends, and perspectives. Crit Rev Environ Sci Technol 41:1449-1530. doi:10.1080/10643381003608326

Chapman L (2007) Transport and climate change: a review. J Transp Geogr 15:354-367. doi:10.1016/j.jtrangeo.2006.11.008

Cornelius P, Van de Putte A, Romani M (2005) Three decades of scenario planning in shell. Calif Manag Rev 48:92-109

Corrêa HL, Corrêa CA (2009) Administração de produção e operações: manufatura e serviços: uma abordagem estratégica. Atlas, São Paulo

Environmental Protection Agency (2006) User's Guide for WARM. In: User's Guide. WARM. http://epa.gov/epawaste/conserve/ tools/warm/Warm_UsersGuide.html. Accessed 13 April 2014

Fujii M, Fujita T, Ohnishi S et al (2014) Regional and temporal simulation of a smart recycling system for municipal organic solid wastes. J Clean Prod 78:208-215. doi:10.1016/j.jclepro. 2014.04.066

Gentil EC, Gallo D, Christensen TH (2011) Environmental evaluation of municipal waste prevention. Waste Manag 31:2371-2379. doi:10.1016/j.wasman.2011.07.030

Greene KL, Tonjes DJ (2014) Quantitative assessments of municipal waste management systems: using different indicators to compare and rank programs in New York State. Waste Manag 34:825-836. doi:10.1016/j.wasman.2013.12.020

Guerrero LA, Maas G, Hogland W (2013) Solid waste management challenges for cities in developing countries. Waste Manag 33:220-232. doi:10.1016/j.wasman.2012.09.008

Herva M, Neto B, Roca E (2014) Environmental assessment of the integrated municipal solid waste management system in Porto (Portugal). J Clean Prod 70:183-193. doi:10.1016/j.jclepro.2014. 02.007

Hoornweg D, Bhada-Tata P, Kennedy C (2013) Environment: waste production must peak this century. Nature 502:615-617. doi:10. $1038 / 502615 \mathrm{a}$

IBGE (2010) Informações sobre os municípios brasileiros. In: Informações sobre os municípios Bras. http://cidades.ibge.gov. br/xtras/home.php. Accessed 13 April 2014

Instituto de Pesquisa Econômica Aplicada (2012) Diagnóstico dos Resíduos Sólidos Urbanos. IPEA, Brasília

IPCC (2014a) Climate change 2014: mitigation of climate change. Contribution of working group III to the 5th assessment report of the intergovernmental panel on climate change. Cambridge, United Kingdom and New York, NY, USA

IPCC (2014b) Climate change 2014: impacts, adaptation, and vulnerability. Part A: global and sectoral aspects. contribution of working group II to the 5th assessment report of the intergovernmental panel on climate change. Cambridge University Press, Cambridge

IPCC (2014c) Climate change 2014: impacts, adaptation, and vulnerability. Part B: regional aspects. Contribution of working group II to the 5th assessment report of the intergovernmental panel on climate change. Cambridge University Press, Cambridge

Jabbour ABLS, Jabbour CJC, Sarkis J, Govindan K (2014) Brazil's new national policy on solid waste: challenges and opportunities. Clean Technol Environ Policy 16:7-9. doi:10.1007/s10098-0130600-z 
Koushki PA, Al-Duaij U, Al-Ghimlas W (2004) Collection and transportation cost of household solid waste in Kuwait. Waste Manag 24:957-964

Lai K, Li L, Mutti S, et al (2014) Evaluation of waste reduction and diversion as alternatives to landfill disposal. In: 2014 Systems and information engineering design symposium (SIEDS). IEEE, pp $183-187$

Larsen AW, Vrgoc M, Christensen TH, Lieberknecht P (2009) Diesel consumption in waste collection and transport and its environmental significance. Waste Manag Res 27:652-659. doi:10.1177/ 0734242 X08097636

Lindgren M, Bandhold H (2003) Scenario planning: the link between future and strategy. Polgrave Macmillan, New York

Lou XF, Nair J (2009) The impact of landfilling and composting on greenhouse gas emissions: a review. Bioresour Technol 100:3792-3798. doi:10.1016/j.biortech.2008.12.006

Mahmoudkhani R, Valizadeh B, Khastoo H (2014) Greenhouse Gases Life Cycle Assessment (GHGLCA) as a decision support tool for municipal solid waste management in Iran. J Environ Health Sci Eng 12:1-7. doi:10.1186/2052-336X-12-71

Massukado LM, Milanez B, Luedemann G, Hargrave J (2013) Diagnóstico da Gestão de Resíduos Sólidos Urbanos no Brasil: uma análise pós PNSB 2008 - ênfase na destinação final e nos resíduos orgânicos. Rev DAE 22-33

Matos F, Dias R (2011) A gestão de resíduos sólidos e a formaçao de consórcios intermunicipais. Rev em Agronegócios e Meio Ambient 4:501-519

Melo LA, Sautter KD, Janissek PR (2009) Estudo de cenários para o gerenciamento dos resíduos sólidos urbanos de Curitiba. Eng Sanit e Ambient 14:551-558. doi:10.1590/S141341522009000400015

Menikpura SNM, Sang-Arun J, Bengtsson M (2013) Integrated solid waste management: an approach for enhancing climate cobenefits through resource recovery. J Clean Prod 58:34-42. doi:10.1016/j.jclepro.2013.03.012

Ministério do Meio Ambiente (2012) Plano nacional de resíduos sólidos. MMA, Brasília

Morrissey AJ, Browne J (2004) Waste management models and their application to sustainable waste management. Waste Manag 24:297-308. doi:10.1016/j.wasman.2003.09.005

Nobre CA, Lapola D, Sampaio G et al (2007) Relatório No. 6. Mudanças Climáticas e possíveis alterações nos Biomas da América do Sul. Ministério da Saúde, São Paulo

Pires A, Martinho G, Chang N-B (2011) Solid waste management in European countries: a review of systems analysis techniques. J Environ Manag 92:1033-1050. doi:10.1016/j.jenvman.2010. 11.024

Premakumara DGJ, Canete AML, Nagaishi M, Kurniawan TA (2014) Policy implementation of the Republic Act (RA) No. 9003 in the
Philippines: a case study of Cebu City. Waste Manag 34:971-979. doi:10.1016/j.wasman.2013.10.040

Santos MFN, Battistelle RAG, Bezerra BS, Varum HSA (2014) Comparative study of the life cycle assessment of particleboards made of residues from sugarcane bagasse (Saccharum spp.) and pine wood shavings (Pinus elliottii). J Clean Prod 64:345-355. doi:10.1016/j.jclepro.2013.06.039

Secretaria do Meio Ambiente (2014a) Plano de Resíduos Sólidos do Estado de São Paulo, 1st edn. SMA, São Paulo

Secretaria do Meio Ambiente (2014b) Município VerdeAzul. http:// www.ambiente.sp.gov.br/municipioverdeazul/. Accessed 17 Jan 2015

Sethi S, Kothiyal NC, Nema AK (2013) Stabilisation of municipal solid waste in bioreactor landfills: an overview. Int J Environ Pollut 51:57-78. doi:10.1504/IJEP.2013.053175

Song Q, Wang Z, Li J (2013) Environmental performance of municipal solid waste strategies based on LCA method: a case study of Macau. J Clean Prod 57:92-100. doi:10.1016/j.jclepro. 2013.04.042

Taheri M, Gholamalifard M, Ghazizade MJ, Rahimoghli S (2014) Environmental impact assessment of municipal solid waste disposal site in Tabriz, Iran using rapid impact assessment matrix. Impact Assess Project Apprais 32:162-169. doi:10.1080/ 14615517.2014.896082

Tan ST, Hashim H, Lim JS et al (2014) Energy and emissions benefits of renewable energy derived from municipal solid waste: analysis of a low carbon scenario in Malaysia. Appl Energy 136:797-804. doi:10.1016/j.apenergy.2014.06.003

Tchobanoglous G, Kreith F (2002) Handbook of solid waste management, 2nd edn. McGraw Hill, New York

Vergara SE, Damgaard A, Horvath A (2011) Boundaries matter: greenhouse gas emission reductions from alternative waste treatment strategies for California's municipal solid waste. Resour Conserv Recycl 57:87-97. doi:10.1016/j.resconrec. 2011.09.011

Worrell W, Vesilind P (2011) Solid waste engineering, 2nd edn. Cengage Learning, Stamford

Yang N, Damgaard A, Lü F et al (2014) Environmental impact assessment on the construction and operation of municipal solid waste sanitary landfills in developing countries: China case study. Waste Manag 34:929-937. doi:10.1016/j.wasman.2014. 02.017

Zaman AU (2013) Identification of waste management development drivers and potential emerging waste treatment technologies. Int J Environ Sci Technol 10:455-464

Zaman AU (2014) Measuring waste management performance using the "Zero Waste Index": the case of Adelaide, Australia. J Clean Prod 66:407-419. doi:10.1016/j.jclepro.2013.10.032 